\title{
Transports of the Brazil and Malvinas Currents at their Confluence
}

\author{
by K. Maamaatuaiahutapu ${ }^{1,2}$, V. Garçon ${ }^{1}$, C. Provost $^{3}$ and H. Mercier ${ }^{4}$
}

\begin{abstract}
Geostrophic transports of the western boundary currents at the Brazil/Malvinas Confluence in the South Atlantic Ocean are estimated from the data set of the Confluence 3 cruise (February 1990) with a nonlinear inverse model which takes into consideration density, current meter and wind data, and dynamical (planetary vorticity, Ekman, mass conservation) constraints. Inversions are carried out with two initial different levels of no motion at $1500 \mathrm{~m}$ (Case A) and at $3000 \mathrm{~m}$ (Case B). Consistencies of the water volume transports provided by both inversions are analyzed and compared to previous estimates.

Current meter constraints are applied in the Malvinas Current region where a total transport of $45 \pm 7 \mathrm{~Sv}\left(1 \mathrm{~Sv}=10^{6} \mathrm{~m}^{3} \mathrm{~s}^{-1}\right)$ is given by both inversions. Within the Brazil Current region, discrepancies between both inversions appear. Case A provides a total transport of $30 \pm 7 \mathrm{~Sv}$ while case B gives a total transport of $56 \pm 8 \mathrm{~Sv}$. In the first two layers $(0-1000 \mathrm{~m} ; 1000-2000 \mathrm{~m})$, case B $(53 \mathrm{~Sv})$ gives larger transport than case A $(32 \mathrm{~Sv})$. North of the Confluence and at the North Atlantic level, water is found to flow northward in case A at a rate of $3.4 \pm 2 \mathrm{~Sv}$ and southward in case B at a rate of $3 \pm 3 \mathrm{~Sv}$. Case B results are more in agreement with our present knowledge of water mass circulation in the Confluence region than case A results. Eastward transports at the Brazil-Malvinas Confluence are estimated to be $20 \pm 7 \mathrm{~Sv}$ and $30 \pm 7 \mathrm{~Sv}$ for cases A and B, respectively. Compared to the total transports of the Brazil and Malvinas Currents, these estimates suggest that most of the water supplied to the Confluence area recirculates within the Brazil Current and the Malvinas Current regions.
\end{abstract}

\section{Introduction}

The Brazil-Malvinas Confluence is identified as the encounter around 38S, of the poleward-flowing Brazil Current and of the equatorward-flowing Malvinas Current along the western margin of the Argentine Basin. The resulting pattern of the surface circulation is the existence of a strong thermohaline front associated with the formation of meanders, eddies and filaments (Legeckis and Gordon, 1982; Olson et al., 1988; Gordon, 1989;

1. Unité Mixte de Recherche 5566, Centre National de la Recherche Scientifique, Groupe de Recherche de Géodésie Spatiale, Toulouse, France.

2. Present Address: University of the South Pacific, Suva, Fiji.

3. Laboratoire d'Océanographie Dynamique et de Climatologie, Centre National de la Recherche Scientifique, Université Paris VI, Paris, France.

4. Laboratoire de Physique des Océans, Unité Mixte de Recherche CNRS/IFREMER, Université de Bretagne Occidentale, IFREMER Centre de Brest, Plouzané, France. 
Peterson and Whitworth, 1989; Peterson and Stramma, 1989). This complex pattern extends as well in the deep layers along the continental slope (Maamaatuaiahutapu et al., 1992, 1994; Bianchi et al., 1993; Provost et al., 1995). The multi-layered water system contributes in intensifying the variability at the Brazil-Malvinas Confluence. Seven water masses have been identified in the Confluence area. Near the surface, the Thermocline Water of subtropical origin and the Subantarctic Surface Water carried by the Brazil and the Malvinas Currents, respectively, meet in approximately the first 800 meters. The $800-1500 \mathrm{~m}$ layer is occupied by the Antarctic Intermediate Water. This water found at shallower depth than $800 \mathrm{~m}$ around $42 \mathrm{~S}$, flows northward. Around the Confluence area, it mixes with a component of the Antarctic Intermediate Water which recirculates with the subtropical gyre (Reid, 1989). Among the deep water masses (1500 m to bottom), the southwardflowing North Atlantic Deep Water meets the Circumpolar Deep Water which separates in two branches as it goes northward, the Lower Circumpolar Deep Water and the Upper Circumpolar Deep Water (see Maamaatuaiahutapuet al., 1992; 1994). Close to the bottom, the Weddell Sea Deep Water presumably flows northward (Georgi, 1981; Reid, 1989; Peterson, 1992; Saunders and King, 1995). Qualitatively, the circulation paths of the different water masses are well defined in the Argentine Basin. Our knowledge about their volume transports is extremely poor. The rare estimates of transport of the boundary currents in the Argentine Basin are deduced from geostrophic computations using hydrographic data (Gordon and Greengrove, 1986; Gordon, 1989; Garzoli and Garraffo, 1989; Stramma, 1989; Peterson, 1992).

The transports of the two major currents as provided by the literature vary on a wide range (Table 1). Of the two currents, the Malvinas Current is the least investigated. First estimates of its transport around the Confluence area have been made by Gordon and Greengrove (1986) who give a value of $10 \mathrm{~Sv}$ at $46 \mathrm{~S}$ and $42 \mathrm{~S}$. The main problem which arises from their computation is the choice of a correct level of no motion in the application of the dynamic method because of the barotropic structure of the Malvinas Current (see Saunders and King, 1995). Thus, Peterson (1992) with the same data set as Gordon and Greengrove (1986), suggests to determine transport of the Malvinas Current as residual quantities from mass balances for an enclosed area constrained by bottom velocities averaged over different time periods. He finds a depth-integrated northward transport in the Malvinas Current region of $75 \mathrm{~Sv}$ at $42 \mathrm{~S}$ and $88 \mathrm{~Sv}$ at 46S. Peterson (1992) argues that his estimates are consistent with transport of the Subantarctic Front at the northward bifurcation of the Antarctic Circumpolar Current near the Drake Passage. Also, the computed velocities are in good agreement with those given by surface drifters. Although Peterson (1992) thought that his values may be overestimated, the Malvinas Current transport must be more robust than the previous estimate of 10 Sv. Recently, Saunders and King (1995) employing the geostrophic shear combined with ADCP data provide a total transport of $50 \mathrm{~Sv}$ at $45 \mathrm{~S}$ for the Malvinas Current. Their results confirm the large transport values of the Malvinas Current and a non-negligible part due to the barotropic component.

Transport of the Brazil Current varies from 15 to $60 \mathrm{~Sv}$ between 33S and 38S (Table 1). 
Table 1. Transport of the Brazil and Malvinas Currents between 33S and 46S.

$\begin{array}{ccc}\text { Transport } & \text { Reference } & \\ (\mathrm{Sv}) & (\mathrm{m}) & \text { Source }\end{array}$

$\begin{array}{llll}\text { Brazil Current } & & & \\ 33 \mathrm{~S} & 17.5 & 1600 & \text { Stramma (1989) } \\ 34 \mathrm{~S} & 15^{\mathrm{a}}, 17^{\mathrm{b}} & 1700 & \text { Zemba (1991) } \\ & 42^{\mathrm{a}}, 27^{\mathrm{b}} & \text { Bottom } & \text { Zemba (1991) } \\ 35.2 \mathrm{~S} & 23 & 1000 & \text { Garzoli (1993) } \\ 36 \mathrm{~S} & 13^{\mathrm{a}}, 37^{\mathrm{b}} & 1400 & \text { Zemba (1991) } \\ & 112^{\mathrm{a}}, 60^{\mathrm{b}} & \text { Bottom } & \text { Zemba (1991) } \\ 36.5 \mathrm{~S} & 23 & 1000 & \text { Garzoli (1993) } \\ 38 \mathrm{~S} & 19 & 1400 & \text { Gordon and Greengrove (1986) } \\ 38 \mathrm{~S} & 18 & 800 & \text { Garzoli and Garraffo (1989) } \\ 38 \mathrm{~S} & 70^{\mathrm{a}}, 28^{\mathrm{b}} & 3000 & \text { Peterson (1992) } \\ 38 \mathrm{~S} & 20 & 1000 & \text { Garzoli (1993) } \\ \text { Malvinas Current } & & & \\ 38 \mathrm{~S} & >5 & 1000 & \text { Garzoli (1993) } \\ 42 \mathrm{~S} & 10 & 1400 & \text { Gordon and Greengrove (1986) } \\ & 75^{\mathrm{a}}, 60^{\mathrm{c}} & 3000 & \text { Peterson (1992) } \\ 45 \mathrm{~S} & 60^{\mathrm{a}}, 50^{\mathrm{b}} & \text { Bottom } & \text { Saunders and King (1995) } \\ 46 \mathrm{~S} & 10 & 1400 & \text { Gordon and Greengrove (1986) } \\ & 88^{\mathrm{a}}, 70^{\mathrm{c}} & 3000 & \text { Peterson (1992) }\end{array}$

aTotal transport.

${ }^{\mathrm{b}}$ Transport for the thermocline water (approximately the first 1000 meters).

'Transport for the first 2000 meters.

In most computations, the level of no motion is chosen at depth shallower than $1700 \mathrm{~m}$ (for only 3 cases out of 11, a deeper level is chosen). The choice of a shallow level of no motion generally is imposed by the data set which often does not reach the bottom. Table 1 shows that according to the reference level the transport of the Brazil Current substantially changes. This also is demonstrated by Zemba (1991). Similarly, Gordon and Greengrove (1986) and Peterson (1992) obtained different values for the transport of the Brazil Current with the same data set.

Due to paucity of data, the transports of the deep western boundary currents around the Confluence area, are rarely determined. Some investigators (Reid et al., 1977; Georgi, 1981; Zemba, 1991; Peterson, 1992) give some transport estimates of the deep core-layers which flow by the Confluence region.

This paper focuses on estimating the transports of the Brazil and Malvinas Currents between $35 \mathrm{~S}$ and $42 \mathrm{~S}$ above the continental slope using a new CTD data set collected during the Confluence 3 cruise (Provost et al., 1990) which is part of the Confluence project (Confluence Principal Investigators, 1990). This data set which covers a time period of 20 days has a high resolution perpendicular to the continent and constitutes our basis for building a nonlinear inverse model and estimating geostrophic transports. The 
inverse model (Mercier et al., 1993) takes into consideration density, current meter and wind data and dynamical (planetary vorticity, Ekman, mass conservation) constraints. Two inversions are carried out with two initial different levels of no motion for geostrophic computations. In Section 2, the data and data-handling procedures are described. In Section 3 , the inverse model is presented with the constraints. Sections 4 and 5 include the analysis of the procedure of inversion while Section 6 groups the transport estimates and the comparison with previous results. The results are finally discussed in Section 7.

\section{Data treatment}

The Confluence 3 cruise took place during the austral summer of 1990 (February 7-27) (Provost et al., 1990; 1995; 1996). The locations of the CTD-O2 stations performed are shown in Figure 1. These stations are distributed along 6 east-west sections perpendicular to the continental slope between $35 \mathrm{~S}$ and $42 \mathrm{~S}$. Along each hydrographic section, the bathymetry varies from about $100 \mathrm{~m}$ to over $4300 \mathrm{~m}$. The distance between two successive stations is $22 \mathrm{~km}$ on the average and is smaller than the average above the continental slope in order to avoid differences in bathymetry greater than $500 \mathrm{~m}$ between neighboring stations.

In this study, we will use a subset of the Confluence 3 CTD-O2. The original vertical resolution of the data set is one meter providing a large amount of data. Because of the computational time of the inversion, the vertical resolution is reduced and only 106 depth levels are used (every $10 \mathrm{~m}$ for the first $200 \mathrm{~m}$, every $20 \mathrm{~m}$ between $200-500 \mathrm{~m}$ and every $50 \mathrm{~m}$ for 500-4000 $\mathrm{m}$ intervals). In order to decrease the amount of data, vertical empirical orthogonal functions of the temperature, salinity and density fields were calculated using a singular value decomposition (see Fukumori and Wunsch, 1991) of the vertical covariance matrices. Horizontal coefficients are then obtained by projecting the original data onto the EOFs. Fifteen functions are shown to be sufficient for a correct reconstruction of the property fields (Maamaatuaiahutapu, 1994). The EOF coefficients were then interpolated onto the regular grid shown in Figure 1 using an objective analysis procedure (Bretherton et al., 1976; Fukumori and Wunsch, 1991). The grid resolution on a new coordinate frame $\mathrm{X}-\mathrm{Y}$ (Fig. 1) is 25 and $50 \mathrm{~km}$ across and along the slope, respectively. The spatial correlation function for the 15 horizontal modes are determined by trial and error in such a way that the obtained circulation pattern is coherently representative of the circulation resolved by our data set. Thus, a sum of two isotropic Gaussian functions with correlation length scales of $25 \mathrm{~km}$ and $150 \mathrm{~km}$ is taken as spatial correlation function.

The $500 \mathrm{~m}$ in situ density field reconstructed with the first 15 EOFs after objective interpolation of its coefficients at the model grid points describes fairly well the circulation in the Confluence region (Fig. 2). Lower density values in the north are associated to the warm Brazil Current. The Brazil Current flowing southward according to our Figure 2, extends over a maximum width of $250 \mathrm{~km}$. Larger density values in the south are due to the cold Malvinas Current. The width of the northward Malvinas Current reaches $250 \mathrm{~km}$. The 


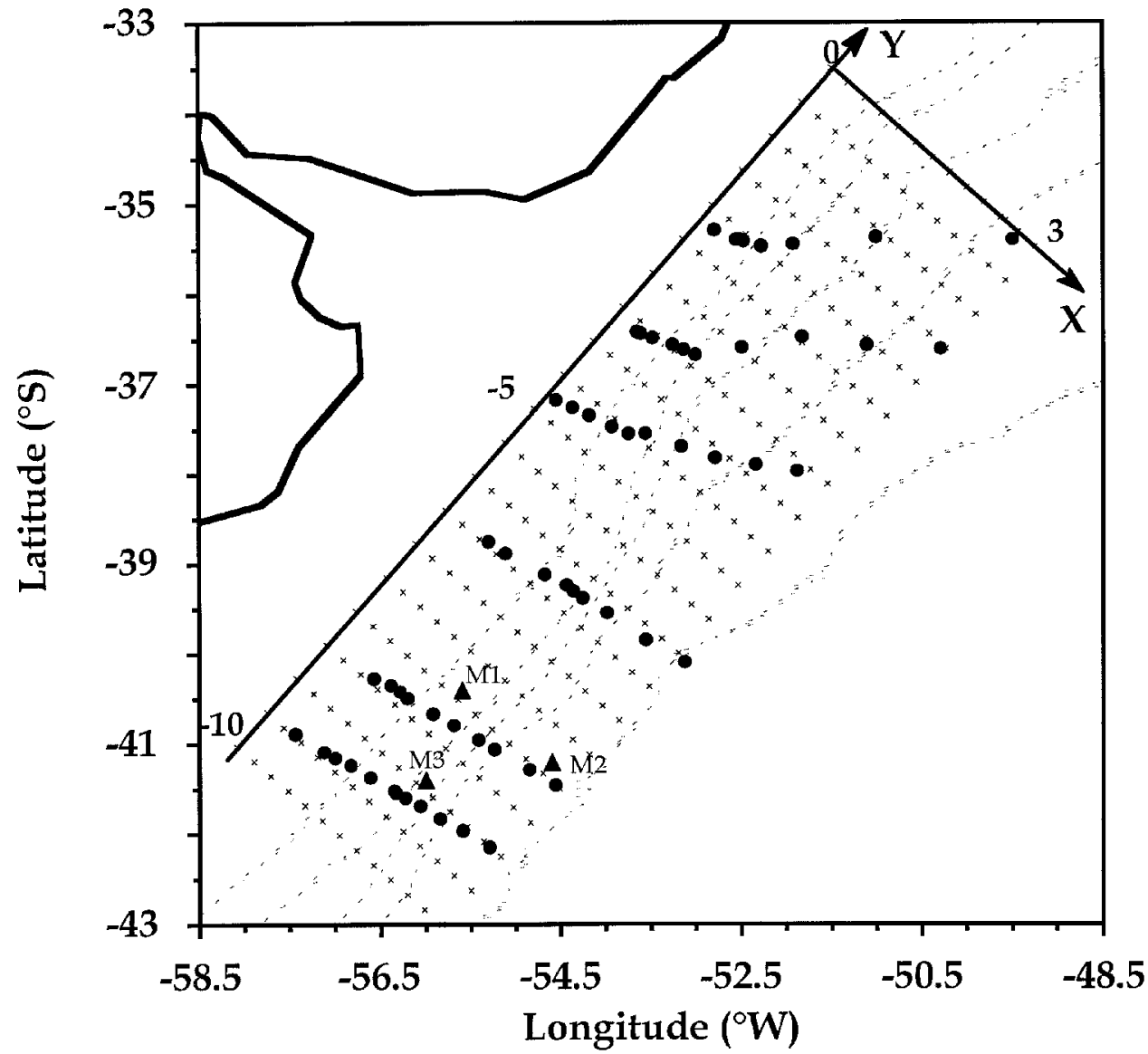

Figure 1. Locations of the CTD stations (circles) of the Confluence 3 cruise, of the three moorings (triangles) and grid model (crosses) used for the inverse model. The steps of the grid are 25 and $50 \mathrm{~km}$ in the seaward and the alongshore direction, respectively. A new (X, Y) coordinate system is defined for the inverse model. One unit in the $0 \mathrm{X}$ or the $0 \mathrm{Y}$ direction is equivalent to $100 \mathrm{~km}$. The $1000,2000,3000,4000,5000$ - $\mathrm{m}$ isobaths are shown.

two major currents encounter around $38 \mathrm{~S}$ to form a seaward flow which will be called hereafter the Jet. The associated statistical error (Fig. 2) is highly correlated with data distribution as it should be for fields resulting from an objective analysis.

Some current meter data (Kartavtseff et al., 1993) will also be introduced in the inverse model as constraints. The locations of the current meter moorings are reported in Figure 1 and current values are given in Table 2. They are averaged values for the Confluence 3 cruise period. The current meter moorings are located south of the Confluence region. We observe that a great variability is found at some locations and within the deep waters. The associated standard deviations are for some data points larger than the average values. 

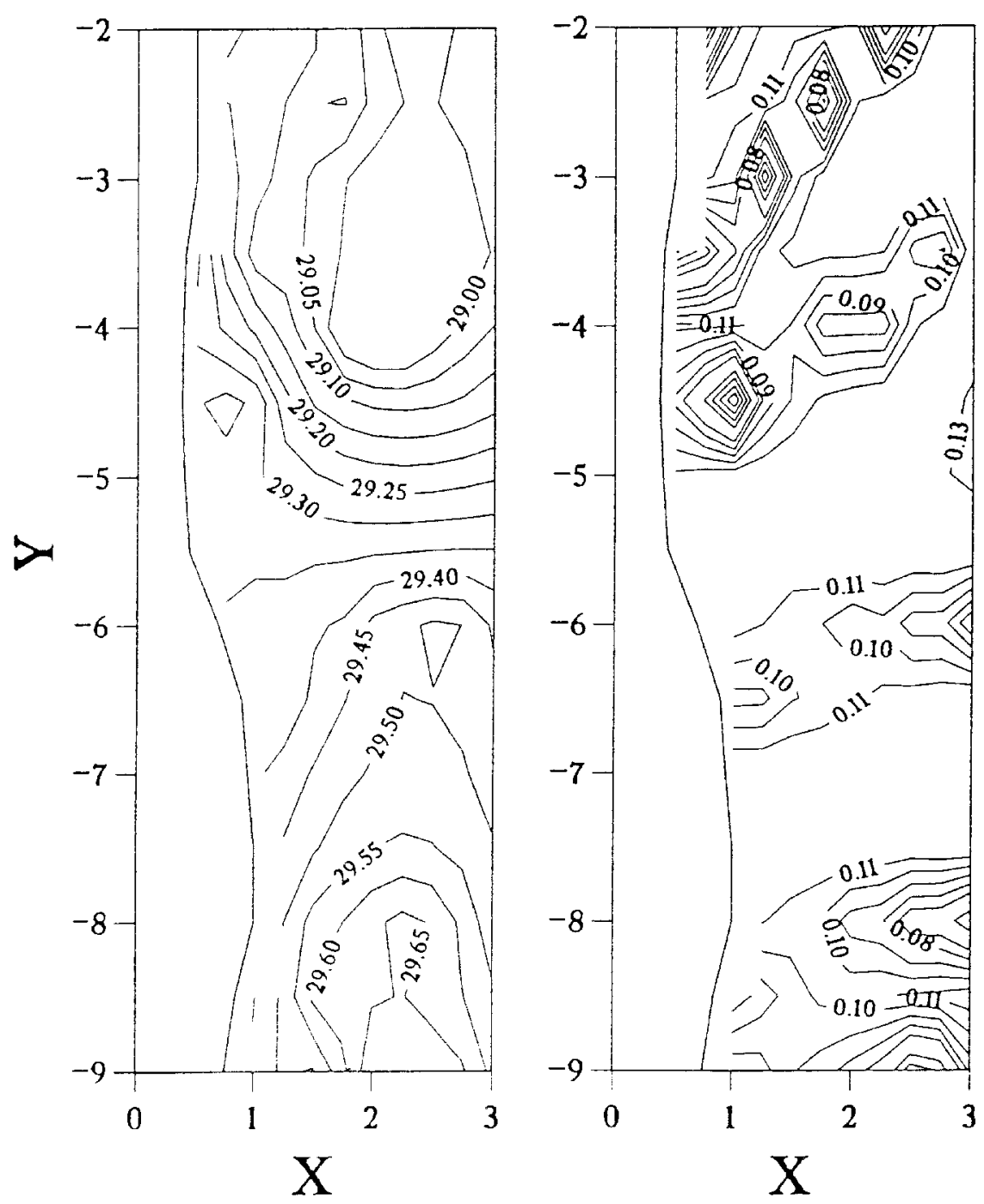

Figure 2. Density field $\left(\mathrm{kg} \mathrm{m}^{-3}\right)$ and associated error at $500 \mathrm{~m}$ reconstructed with 15 objectively analyzed modes. The $500 \mathrm{~m}$ isobath is shown.

\section{The nonlinear and geostrophic inverse model}

The purpose of the nonlinear inverse model is to search for horizontal reference velocities and a density field at model grid points as close as possible from the density data while satisfying the dynamical and current meter constraints. Hogg (1987) and Zhang and Hogg (1992) formulated a similar but linear inverse model: residuals were allowed in the thermal wind relation, which account for both errors in the density field and deviations of the actual flow from perfect thermal wind relation. Given the density and reference velocity 
Table 2. Averaged east and north components of the velocity derived from current meters. These values are averaged over the 20-day period corresponding to the Confluence 3 cruise.

$\begin{array}{ccccr}\text { Moorings } & \text { Position } & \begin{array}{c}\text { Depth } \\ (\mathrm{m})\end{array} & \begin{array}{c}\text { East } \\ \text { component } \\ \left(\mathrm{cm} \mathrm{s}^{-1}\right)\end{array} & \begin{array}{r}\text { North } \\ \text { component } \\ \left(\mathrm{cm} \mathrm{s}^{-1}\right)\end{array} \\ \text { M1 } & -55.6 \mathrm{~W},-40.4 \mathrm{~S} & 1000 & 12 \pm 1.9 & 8.7 \pm 1.8 \\ \text { M2 } & -54.6 \mathrm{~W},-41.2 \mathrm{~S} & 1800 & 0.9 \pm 2.9 & 1.9 \pm 0.6 \\ \text { M2 } & -54.6 \mathrm{~W},-41.2 \mathrm{~S} & 2500 & 1.6 \pm 4.0 & -5.4 \pm 8.3 \\ \text { M3 } & -56.0 \mathrm{~S},-41.4 \mathrm{~S} & 1800 & 2.8 \pm 2.5 & 5.8 \pm 4.3 \\ \text { M3 } & -56.0 \mathrm{~S},-41.4 \mathrm{~S} & 2600 & 2.6 \pm 1.2 & 2.9 \pm 1.1\end{array}$

fields one can compute the horizontal components of the velocity field using the thermal wind relationship and the vertical velocity field is obtained from the divergence of the horizontal velocities integrated from the bottom. At the sea floor, the condition of no flux into the bottom is applied. Mathematically, the problem is equivalent to minimize in a least squares sense the scalar $S$ :

$$
\begin{gathered}
S=\left(\boldsymbol{d}-\boldsymbol{d}_{\mathbf{0}}\right)^{T} \cdot C_{d_{0}}^{-1} \cdot\left(\boldsymbol{d}-\boldsymbol{d}_{\mathbf{0}}\right)+\left(\boldsymbol{V}-\boldsymbol{V}_{\mathbf{m}}\right)^{T} \cdot C_{V_{m}}^{-1} \cdot\left(\boldsymbol{V}-\boldsymbol{V}_{\mathbf{m}}\right) \\
\left(\boldsymbol{V}_{\boldsymbol{r}}-\boldsymbol{V}_{\boldsymbol{r}_{0}}\right)^{T} \cdot C_{V_{r_{0}}}^{-1} \cdot\left(\boldsymbol{V}_{\boldsymbol{r}}-\boldsymbol{V}_{\boldsymbol{r}_{0}}\right)+\boldsymbol{m}^{T} \cdot C_{m}^{-1} \cdot \boldsymbol{m}
\end{gathered}
$$

The first term expresses the adjustment of the density field defined by the vector $\boldsymbol{d}$. The vector $\boldsymbol{d}_{\boldsymbol{0}}$ is the initial density field determined with an objective analysis with its associated covariance matrix $C_{d_{0}}$. In practice, the density field is reconstructed using fifteen vertical modes defined by the singular value decomposition and the elements of $\boldsymbol{d}$ are then the EOF coefficients at each grid point. The number of density parameters to be adjusted by the inversion is then equal to the number (195) of grid points times the number (15) of modes.

The second term compares the computed velocities (vector $\boldsymbol{V}$ ) and the measured velocities (vector $\boldsymbol{V}_{\boldsymbol{m}}$ ) at the mooring locations. This term is referred to as the current meter constraints. The associated error matrix $C_{V_{m}}$ is taken diagonal and contains the variance of each measured value during the Confluence 3 cruise (Table 2). These constraints amount to a small number since the current meters only give 10 values, 5 alongshelf and 5 seaward velocities.

The third term is the horizontal velocity adjustment at the reference level. The vector $\boldsymbol{V}_{\boldsymbol{r}}$ contains the estimated horizontal reference velocities at the reference (182 for the zonal components and 180 for the meridional component) level while $\boldsymbol{V}_{\boldsymbol{r}_{\boldsymbol{0}}}$ is the vector containing the initial horizontal velocities at the reference level which in here is assumed equal to the null vector. To ease the comparison of our results and those found in the literature, the inverse model is run twice with first a reference level at $1500 \mathrm{~m}$, case A, and second with a reference level at $3000 \mathrm{~m}$, case $\mathrm{B}$. The bottom depth is taken when the greater CTD station depth is shallower than the reference level. The associated error matrix $C_{V_{r 0}}$ is taken diagonal. Stable inversions are obtained with a small value of the error (Jackson, 1979). Table 2 displays large variability in the velocity field at great depth suggesting large 
uncertainties at the reference level. For this reason and for stability sake in the inversion procedure, a standard deviation of $3 \mathrm{~cm} \mathrm{~s}^{-1}$ has been chosen.

The last term encompasses the constraints which force the circulation to satisfy mass conservation, Ekman pumping at the surface and conservation of the planetary vorticity at the reference level. These constraints called dynamical constraints are formulated using a finite-difference scheme on the model grid (Mercier et al., 1993). The grid model is adapted to our problem by a rotation in order to compute alongshelf and seaward components of velocity. The associated error matrix $C_{m}$ contains variances of these constraints defined for each cell.

Mass conservation is applied to each cell by integration of $\rho u$ (density times corresponding velocity) from bottom to surface, along the cell boundary. Here $u$ is the horizontal component of total (geostrophic plus Ekman) velocity. Possible residuals are the mass flux at the air-sea interface and the interior mixing due to the contribution of unresolved small scales. The error of the mass conservation is of the order of the mass flux at the air-sea interface plus the contribution of the eddy terms. A mean air-sea interface mass flux is estimated with the formulae given by Schmitt et al. (1989) and a value of $310^{-6} \mathrm{~kg} \mathrm{~m}^{-2} \mathrm{~s}^{-1}$ is obtained (Maamaatuaiahutapu, 1994). The small-scale eddy contribution is more difficult to evaluate. A standard deviation of $310^{-6} \mathrm{~kg} \mathrm{~m}^{-2} \mathrm{~s}^{-1}$ is finally taken for the conservation constraint.

The Ekman theory is applied through the minimization of the imbalance between the vertical flux at the bottom of the surface layer computed from the integration from the bottom of the divergence of the horizontal geostrophic velocities and the horizontal flux divergence of the Ekman and geostrophic horizontal volume fluxes in the surface layer. The vertically integrated Ekman velocity is computed as Gill (1982) with mean sea-surface wind stress from the European Center for Medium Range Weather Forecast (ECMWF) model during the Confluence 3 cruise. Wind stress data available every 1.125 degree in longitude and latitude are linearly interpolated to our model grid points. The Ekman layer is arbitrarily taken at $25 \mathrm{~m}$ at mid-depth of the seasonal thermocline well marked over the whole region during the cruise period. The standard error in the Ekman constraints is taken to be equal to the standard deviation of the Ekman vertical velocity field $\left(10^{-4} \mathrm{~m} \mathrm{~s}^{-1}\right)$ multiplied by the corresponding cell area. It is hoped that this will account for the errors in the data as well as for the neglected terms in the diagnosis of the vertical velocity.

The geostrophic current divergence being equal to $\beta v / f$ ( $f$ is the Coriolis parameter and $\beta$ is equal to $d f / d y)$, the balance $\beta v=f(\partial w / \partial z)$ is implicitly verified by the inverse model, except at the reference level where it has to be specified as a constraint. This constraint will be called vorticity constraint even though it only encompasses planetary vorticity. Vorticity estimates in the Confluence area are poor. On comparing to the Gulf Stream region (see Bower, 1989), we finally chose a standard deviation in speed unit of $10^{-6} \mathrm{~m} \mathrm{~s}^{-1}$. This value is hoped to encompass eddy and shear contributions which are not negligible in the Confluence area.

The topography comes from the National Geological Data Center 5' base. A smoothed 
topography of the Confluence region at grid points is obtained by averaging existing data within a radius of $25 \mathrm{~km}$. A change in the slope (Fig. 1) of the topography occurs at 38S. This may have some implications on the circulation scheme of the water masses.

Because of computation time required to obtain the output uncertainty estimates on the solution, the parameters are presumed independent. The root mean square (rms) of the solutions (the EOF coefficients and the reference-level velocity components) are thus computed using the formula proposed by Tarantola and Valette (1982).

In summary the inverse model looks for estimates of the EOF coefficients (the $15 \times 195$ elements of $\boldsymbol{d})$ and reference-level velocity components $\left(182+180\right.$ elements of $\left.\boldsymbol{V}_{\boldsymbol{r}}\right)$ by minimizing the scalar $S$. Besides the a priori estimates $\boldsymbol{d}_{\boldsymbol{0}}$ and $\boldsymbol{V}_{\boldsymbol{r}_{\boldsymbol{\theta}}}$ (3287 elements), there are 168 planetary vorticity constraints, 168 Ekman constraints, 168 mass conservation constraints and 10 current meter constraints.

\section{The a priori field}

The inversion will be carried out with two choices of level of no motion. The choice for the level of no motion for geostrophic computation has been for a long time a subject of controversy. It still is the case, particularly along the western boundary of the South Atlantic Ocean where information about the flow field is scarce (Stramma, 1989; Zemba, 1991; Peterson, 1992). Around the Confluence region, the literature (Table 1) leads us to consider two groups. The first group includes authors who had taken a level of no motion in the interval depth of $800 \mathrm{~m}$ and $1700 \mathrm{~m}$. For most authors, the choice has been imposed by their data set which does not reach the bottom depth (Gordon and Greengrove, 1986; Roden, 1986; Gordon, 1989). The second group recently formed (Zemba, 1991; Peterson, 1992) considers a level of no motion at a greater depth varying between $3000 \mathrm{~m}$ and the bottom depth. From these considerations, two levels of no motion will be chosen to start the inversion. The first one is chosen at a depth of $1500 \mathrm{~m}$ (case A) and the second at a depth of $3000 \mathrm{~m}$ (case B) and at the bottom depth wherever it is shallower. In this section, we will discuss the a priori (before inversion) field and the residuals of the different constraints obtained according to the choice of the two levels of no motion.

The a priori $500 \mathrm{~m}$ velocity fields relative to $1500 \mathrm{~m}$ (Case A) and to $3000 \mathrm{~m}$ (Case B) (Fig. 3) computed from the objectively analyzed density field (see for example Fig. 2), perfectly describe the two dominant currents with their confluence around 38S. Similar patterns are obtained with the two reference levels. However, velocity norms are lower for case A than for case B. In case A (case B), maximum values of $43 \mathrm{~cm} \mathrm{~s}^{-1}\left(53 \mathrm{~cm} \mathrm{~s}^{-1}\right), 57$ $\mathrm{cm} \mathrm{s}^{-1}\left(63 \mathrm{~cm} \mathrm{~s}^{-1}\right)$, and of $72 \mathrm{~cm} \mathrm{~s}^{-1}\left(96 \mathrm{~cm} \mathrm{~s}^{-1}\right)$ are obtained for the seaward component, the Brazil Current, and the Malvinas Current, respectively. Our values for the Malvinas Current are on the same order of magnitude as those given by Garzoli (1993). The standard errors in the a priori $500 \mathrm{~m}$ velocity (Fig. 3 ) include both the contribution of velocity errors at the reference level and the contribution of errors in the density field, the latter being the most important.

The statistics of the a priori residuals of the constraints are grouped in Table 3 . The mean 

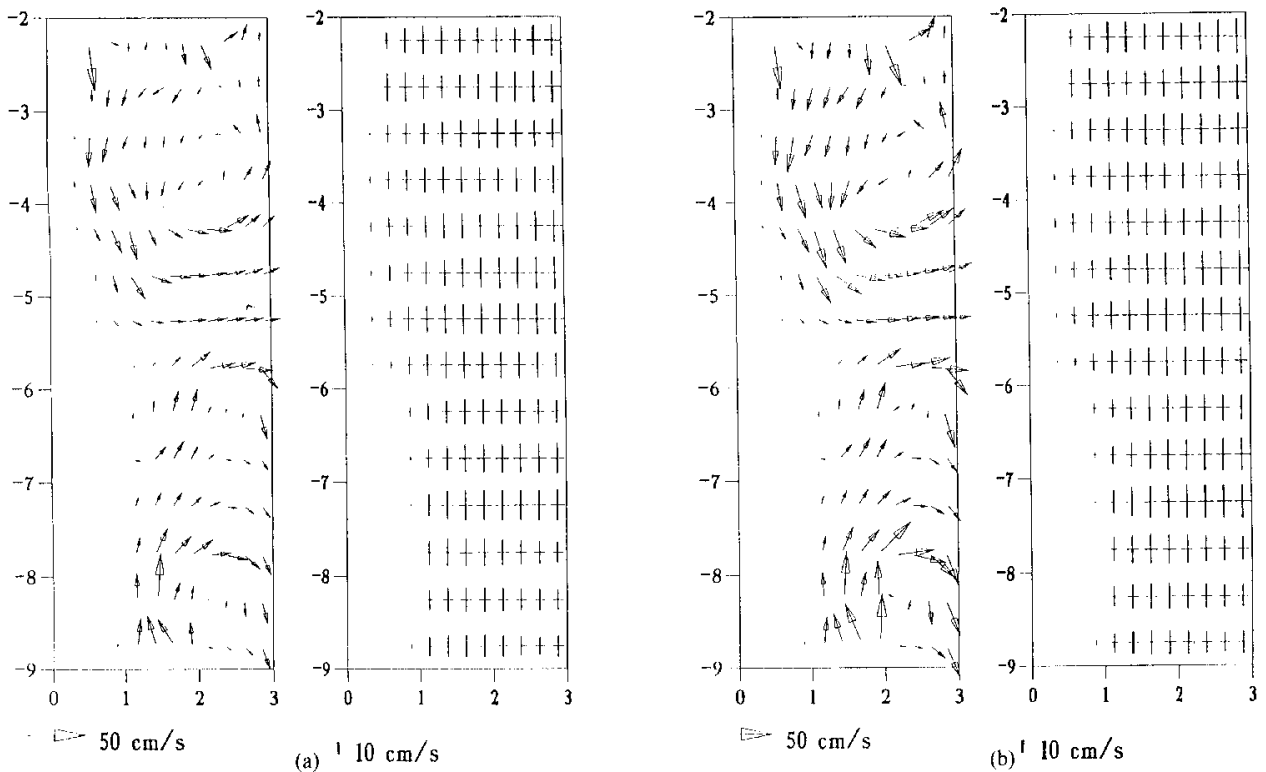

Figure 3. (a) A priori velocity field (cm/s) and associated standard errors ( $\mathrm{cm} / \mathrm{s})$ at $500 \mathrm{~m}$ from the $1500 \mathrm{~m}$ reference level (case A). The errors of the velocity components in $\mathrm{X}$ and $\mathrm{Y}$ directions are displayed as horizontal and vertical lines, respectively.(b) Same except from the $3000 \mathrm{~m}$ reference level (case B).

a priori residual of the mass conservation constraints corresponds to a gain (case $\mathrm{A}$ ) or a loss (case B) of mass of $0.1310^{9} \mathrm{~kg} \mathrm{~s}^{-1}$ for each cell. Considering the surface of a cell, this is equivalent to a mass flux at the air-sea interface of about $0.1 \mathrm{~kg} \mathrm{~m}^{-2} \mathrm{~s}^{-1}$. With the hypothesis that exchange of matter only occurs at the sea surface, this value appears extremely high. Schmitt et al. (1989) report maximum values of density flux at the air-sea interface of about $10^{-5} \mathrm{~kg} \mathrm{~m}^{-2} \mathrm{~s}^{-1}$ in the North Atlantic. This maximum observed in the region of the Gulf Stream is well below our mean residual value.

The a priori residuals of the Ekman and vorticity constraints are listed in Table 3 in units of vertical velocity. The average residuals of the Ekman constraint for both cases A and B are about $10^{-4} \mathrm{~m} \mathrm{~s}^{-1}$. The associated standard deviation indicate that the vertical velocity norms at the base of the Ekman layer can reach values of about $10^{-3} \mathrm{~m} \mathrm{~s}^{-1}$. For cases A and $\mathrm{B}$, the average residual of the vorticity constraint is about $10^{-6} \mathrm{~m} \mathrm{~s}^{-1}$ and the standard deviation is around $10^{-5} \mathrm{~m} \mathrm{~s}^{-1}$. The overall average norm of the vertical velocity is $710^{-4} \mathrm{~m} \mathrm{~s}^{-1}$ and $410^{-3} \mathrm{~m} \mathrm{~s}^{-1}$ for cases A and B, respectively. In the Gulf Stream region, the vertical velocities norms vary from $10^{-5} \mathrm{~m} \mathrm{~s}^{-1}$ to $10^{-4} \mathrm{~m} \mathrm{~s}^{-1}$ (Hall, 1986; Bower and Rossby, 1989; Liu and Rossby, 1993). The comparison of the vertical velocities obtained in the Confluence region with those computed in the Gulf Stream region shows that there is a large discrepancy. Caution must be taken in this comparison because we do neglect the contribution due to ageostrophic process. Since we do not have any information, we will, 
Table 3. Statistics of the residuals of the constraints (dynamical and current meter) over the region computed with the a priori velocity field. The mean residual of a constraint is obtained by taking the total residual divided by the total number of cells where the constraint is applied. The standard deviations reflect the variations of the residual over the whole area of confluence. Also reported is the a priori standard deviation (which is the weighting factor) associated with each constraint.

Model

Reference

Constraint

$\operatorname{Ekman}\left(\mathrm{m} \mathrm{s}^{-1}\right)$

Mass Conservation $\left(\mathrm{kg} \mathrm{s}^{-1}\right)$

Vorticity $\left(\mathrm{m} \mathrm{s}^{-1}\right)$

Current Meter $\left(\mathrm{m} \mathrm{s}^{-1}\right)$
A

$1500 \mathrm{~m}$
B

$3000 \mathrm{~m}$

$\begin{array}{ccccc}\text { Mean } & \text { Stand. } & \text { Mean } & \text { Stand. } & \text { A priori } \\ \text { residual } & \text { Dev. } & \text { residual } & \text { Dev. } & \text { Dev. }\end{array}$

however, consider in comparison with the Gulf Stream region that these vertical velocities are too high to be considered realistic.

For the current meter constraints, the average residual from case A is larger than that from case B (Table 3). The associated standard deviation shows that the difference between the horizontal geostrophic velocity and the measured velocity easily reaches values higher than $0.05 \mathrm{~m} \mathrm{~s}^{-1}$.

Finally, the a priori total mass balance over the domain is equal in norm to $21 \mathrm{~Sv}$ in the two cases of reference level choice. The difference is that $21 \mathrm{~Sv}$ are gained in case A in accordance with the density flux whereas $21 \mathrm{~Sv}$ are lost in case B. This value corresponds to the amount of water volume transport to be corrected by our inversion assuming that the total mass is conserved. As exhibited by the high residual values, the a priori field from both a priori inversions does not satisfy the constraints.

\section{The a posteriori field}

Before exploiting the output of an inverse model, it is crucial to look at the residuals of the constraints and at the parameter adjustment which show the improvement of the solution by the dynamical and the current meter constraints. For the constraints, we compare the mean a posteriori residual value to the mean a priori residual with respect to the a priori imposed standard deviation. For the parameters, we compare the rms of the estimated solution to the a priori imposed standard deviation.

\section{a. The constraint}

The a posteriori constraint residuals (Table 4) have to be compared to the a priori ones (Table 3). Compared to the a priori residuals, a net decrease is observed for most of the residuals except for the direct constraints by current meter data in case B.

Statistically, the current meter constraints (10 constraints included in our inversion) are respected in both inversions even though the mean residual increases for case $B$. This 
Table 4. Statistics of the residuals of the constraints computed with the a posteriori velocity field. The mean residual of a constraint is obtained by taking the total residual divided by the total number of cells where the constraint is applied. The standard deviations reflect the variations of the residuals over the whole area of Confluence. $n$ is the number of constraints which standard deviations are higher than once the average $a$ posteriori standard deviation. $n 0$ is the total number of different constraints applied in the inverse procedure.

Model

Reference

Constraint

Ekman $\left(\mathrm{m} \mathrm{s}^{-1}\right)$

Mass Conservation $\left(\mathrm{kg} \mathrm{s}^{-1}\right)$

Vorticity $\left(\mathrm{m} \mathrm{s}^{-1}\right)$

Current meter $\left(\mathrm{m} \mathrm{s}^{-1}\right)$
A

$1500 \mathrm{~m}$
B

$3000 \mathrm{~m}$

$\begin{array}{lccccccc} & \begin{array}{c}\text { Mean } \\ \multicolumn{1}{c}{\text { Constraint }} \\ \text { residual }\end{array} & \begin{array}{c}\text { Stand. } \\ \text { Dev. }\end{array} & n & \begin{array}{c}\text { Mean } \\ \text { residual }\end{array} & \begin{array}{c}\text { Stand. } \\ \text { Dev. }\end{array} & n & n 0 \\ \text { Ekman }\left(\mathrm{m} \mathrm{s}^{-1}\right) & -.2210^{-5} & .7410^{-5} & 8 & -.1810^{-5} & .4910^{-5} & 6 & 168 \\ \text { Mass Conservation }\left(\mathrm{kg} \mathrm{s}^{-1}\right) & .2910^{2} & .5010^{3} & 11 & .4210^{2} & .4510^{3} & 1 & 168 \\ \text { Vorticity }\left(\mathrm{m} \mathrm{s}^{-1}\right) & .2710^{-6} & .6610^{-6} & 18 & .1610^{-6} & .4110^{-6} & 4 & 168 \\ \text { Current meter }\left(\mathrm{m} \mathrm{s}^{-1}\right) & .006 & .026 & 4 & .014 & .03 & 3 & 10\end{array}$

increase of the mean residual may be due to the fact that the current meter data are averaged over one month and give a figure of the flow field picture which does not always agree with the one given by the CTD data. Also, the current meter data contain more information than the CTD data from which only geostrophic information is generally deduced. This problem, an ageostrophic one, is discussed by Saunders and King (1995) where they compare ADCP data and geostrophic estimates. Differences are essentially due to transient ageostrophic currents, tides and inertial oscillations.

The most impressive decrease of the residuals is attributed to the mass conservation constraint. The average residual value of $10^{2} \mathrm{~kg} \mathrm{~s}^{-1}$ corresponds more to realistic mass flux value at the air-sea interface.

The Ekman and the vorticity constraints have their a posteriori residuals lower than $a$ priori ones. Whatever the chosen level of no motion, the average vertical velocity norm has diminished. Average values of vertical velocities of $510^{-5} \mathrm{~m} \mathrm{~s}^{-1}$ and of $910^{-5} \mathrm{~m} \mathrm{~s}^{-1}$ are obtained for cases $\mathrm{A}$ and $\mathrm{B}$, respectively. Maximum values of vertical velocities are $210^{-3} \mathrm{~m} \mathrm{~s}^{-1}$ and $510^{-4} \mathrm{~m} \mathrm{~s}^{-1}$ for cases $\mathrm{A}$ and $\mathrm{B}$ respectively.

\section{b. The parameters}

The average parameter offset quantitatively indicates how the parameters change (Fig. 4). Figure 4 shows that most of the parameter offsets are larger for case A than for case B. The alongshelf component of the velocity at the reference level of case A gives a residual value exceeding $80 \%$ while the seaward component residual is more than $50 \%$. Case B provides offsets of the velocity components well below $50 \%$ at its reference level. On comparing cases $\mathrm{A}$ and $\mathrm{B}$, these values indicate that in the case of a direct computation of geostrophic velocities in the Confluence area, the $3000 \mathrm{~m}$ reference level of no motion is more appropriate.

The horizontal velocity fields at the reference level of both inversions are displayed on Figure 5. The velocity norms at depth $1500 \mathrm{~m}$ of case A exceed by a large amount those 


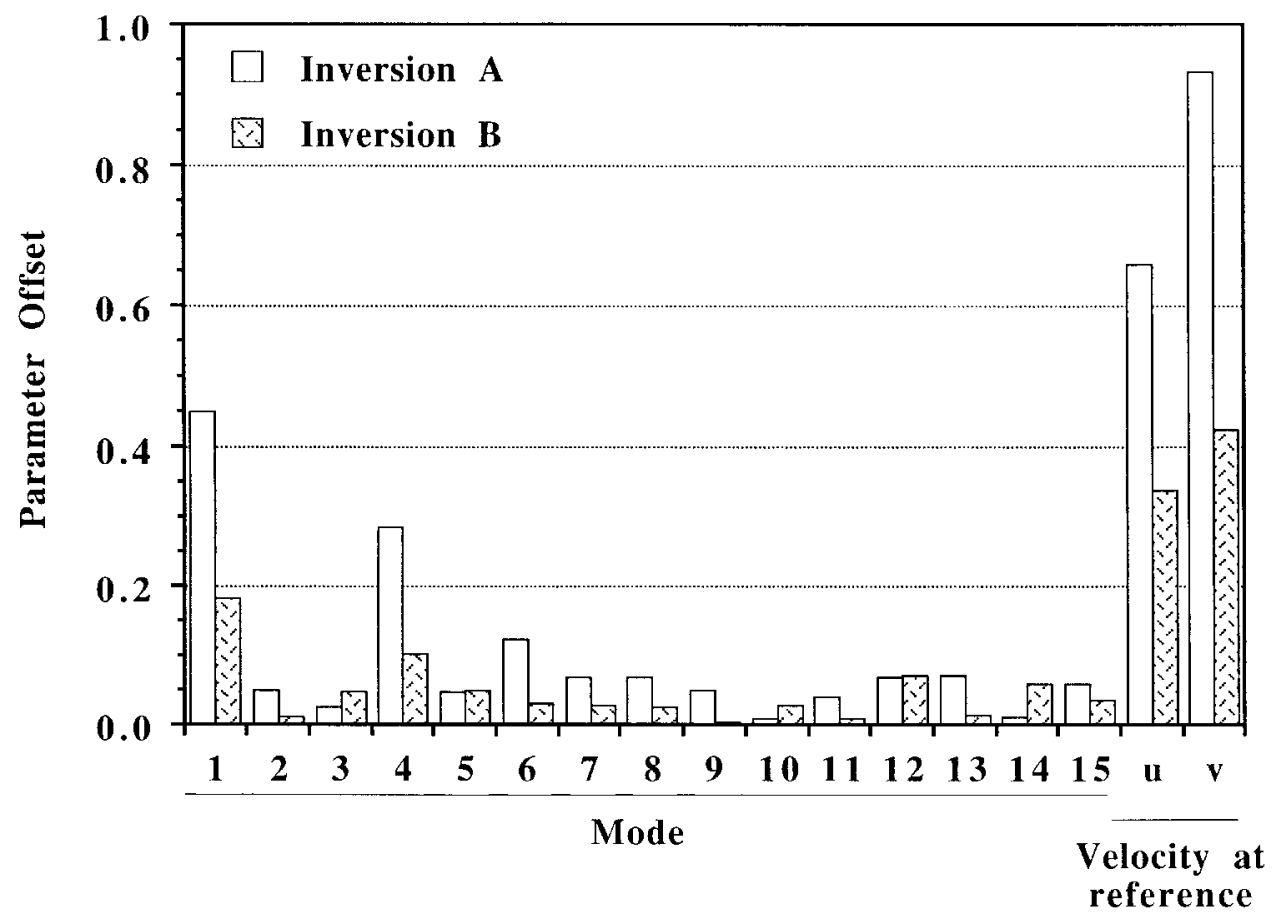

Figure 4. Offsets of the parameters (EOFs of the density field and horizontal reference velocities) relative to the a priori values, normalized by the root mean squared of the estimated solution, for cases $\mathrm{A}$ and $\mathrm{B}$.

found on the $3000 \mathrm{~m}$ level of case B. The circulation pattern given by case A on its reference level reflects the surface circulation scheme. The distribution of the rms of the estimated solution (Fig. 5) shows a net decrease of the rms associated to the seaward component of the velocity components at the reference level.

The EOF coefficient offsets are also larger for case A than for case B (Maamaatuaiahutapu, 1994). It shows that case A has to modify the a priori density field by a non-negligible amount in order to satisfy the constraints. The density field with its associated error are reported on Figure 6 for the particular depth of $500 \mathrm{~m}$. The main changes in the density field are apparent for case B in the Malvinas Current region.

The main correction which the inversion has to perform is to reduce the a priori total mass balance of $21 \mathrm{~Sv}$. The correction of the mass balance practically is taken into account by the adjustment of the horizontal velocities at the reference level for case B. For case A, the coefficients of the first and the fourth modes have to be modified too. Table 4 reports the numbers of constraints of which a posteriori standard deviations are higher than the $a$ priori standard deviations. If we consider those constraints as rejected by the inversion, we see that those numbers are small (41 for case A and 14 for case B, for a total number of constraints of 514). Thus, a small amount of constraints has to be rejected. Thus, in most 


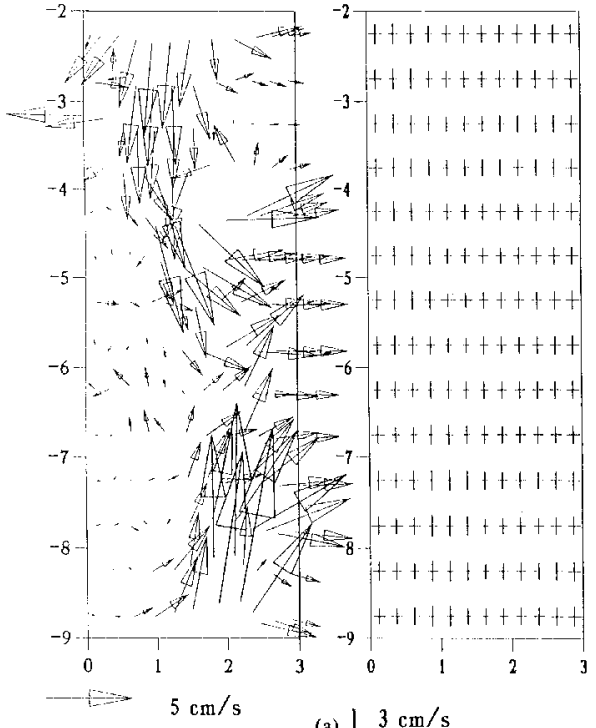

(a) $13 \mathrm{~cm} / \mathrm{s}$
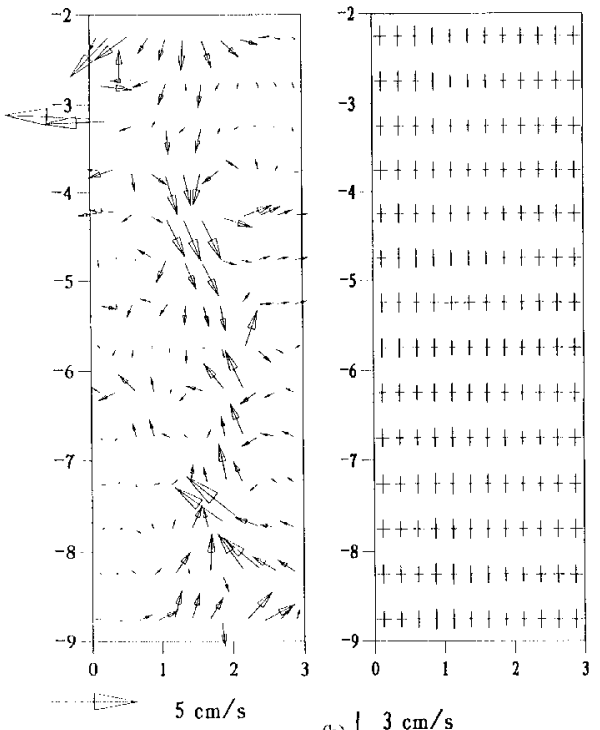

(b) $13 \mathrm{~cm} / \mathrm{s}$

Figure 5. (a) Velocity field $(\mathrm{cm} / \mathrm{s})$ and associated standard errors $(\mathrm{cm} / \mathrm{s})$ on reference level from the $1500 \mathrm{~m}$ reference model (case A). The errors of the velocity components in $\mathrm{X}$ and $\mathrm{Y}$ directions are displayed as horizontal and vertical lines, respectively.(b) Same except from the $3000 \mathrm{~m}$ reference model (case B).

cases, the constraints are compatible with the hydrographic data. Less constraints are rejected by case $\mathrm{B}$ than by case $\mathrm{A}$. We have pointed out in discussing the parameters that the best reference level is the depth of $3000 \mathrm{~m}$. The constraint analysis seems to confirm this idea. Whatever the conclusion at this stage, we will proceed with our investigation by comparing the transport provided by both cases.

\section{The transport of the major currents}

The water volume transport estimates (Fig. 7) are given for the Brazil Current, the Malvinas Current and the Jet (Brazil-Malvinas Confluence) regions. The Jet region corresponds here to the area where intense seaward currents perpendicular to the continental slope are obtained.

The transport estimates of case A are provided on Figure 7a. The vertically integrated transports are reported on the horizontal map. When looking at the transport distribution according to the layer in the region of the Brazil Current, the depth-integrated transport of $30 \pm 7 \mathrm{~Sv}$ is equivalent to the southward transport of the first thousand meters. The transports of the deep layers compensate each other: water flowing southward in the 1000-2000 m layer and northward in the 2000-3000 m layer. The latter encompasses the North Atlantic Deep Water which is known to flow southward. Beneath $3000 \mathrm{~m}$ depth, the Weddell Sea Deep Water is found to flow northward at a rate of $1 \mathrm{~Sv}$. The $30 \pm 7 \mathrm{~Sv}$ found 


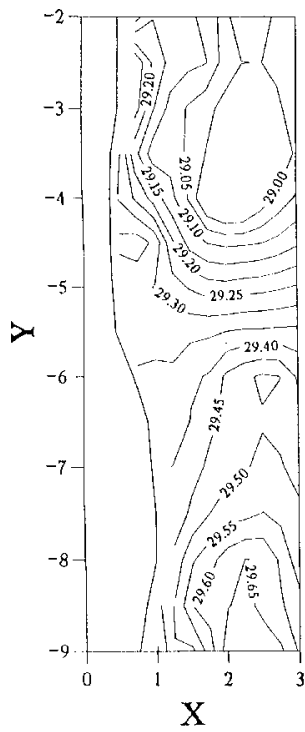

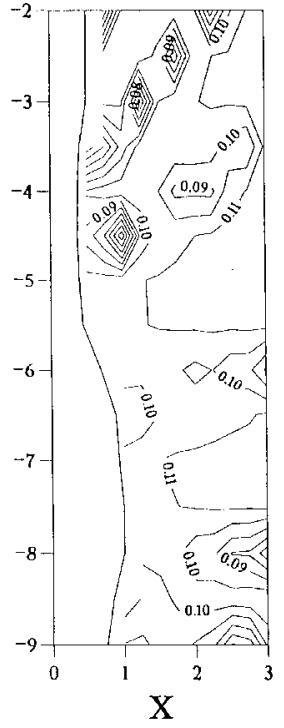

(a)
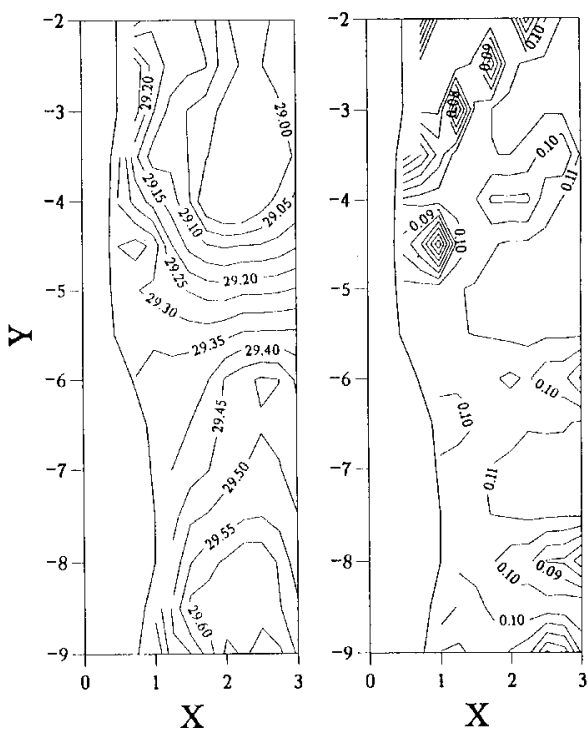

(b)

Figure 6. (a) A posteriori density field $\left(\mathrm{kg} \mathrm{m}^{-3}\right)$ and associated error at $500 \mathrm{~m}$ for the $1500 \mathrm{~m}$ reference model (case A). The $500 \mathrm{~m}$ isobath is shown. (b) Same except for $3000 \mathrm{~m}$ reference level (case B).

for the Brazil Current falls within the 28-37 Sv interval which limits correspond to the transports given by Peterson (1992) at $38 \mathrm{~S}$ (level of no motion at $3000 \mathrm{~m}$ ) and by Zemba (1991) at 36S (level of no motion at $1400 \mathrm{~m}$ ), respectively. The transport value of our surface layer (which includes the Thermocline Water and the Antarctic Intermediate Water) is also comparable to that of Garzoli (1993) who gives an average transport of $23 \mathrm{~Sv}$ at $36 \mathrm{~S}$ for the first thousand meters.

In the Malvinas Current region, the flow scheme is simple since the whole water column moves northward. Thus, the $46 \pm 7 \mathrm{~Sv}$ depth-integrated transport is mainly due to the surface layer with a transport of $37 \pm 6 \mathrm{~Sv}$. The last result has to be compared to those provided by Gordon and Greengrove (1986). They found a maximum transport of $10 \mathrm{~Sv}$ at 42S. Even though farther in the north, we provide a higher transport for the Malvinas Current with almost the same reference level of no motion. Our transport estimate of the surface layer is more in agreement with that given by Peterson (1992) at $42 \mathrm{~S}$ or by Saunders and King (1995) at 45S. We will see later that this transport estimate remains consistent with that given by case B. The discrepancies between the results of case A and Peterson (1992) come from the transports of the deep layers where our values are lower.

The new feature presented here is the transport of the Jet. The Jet is considered as a narrow vein in which water is flowing perpendicularly to the continental slope (Fig. 7). The total seaward transport of $20 \pm 7 \mathrm{~Sv}$ is confined to the surface layer. This value is low if we consider that the quantity of water carried by the two major currents must be added to form 

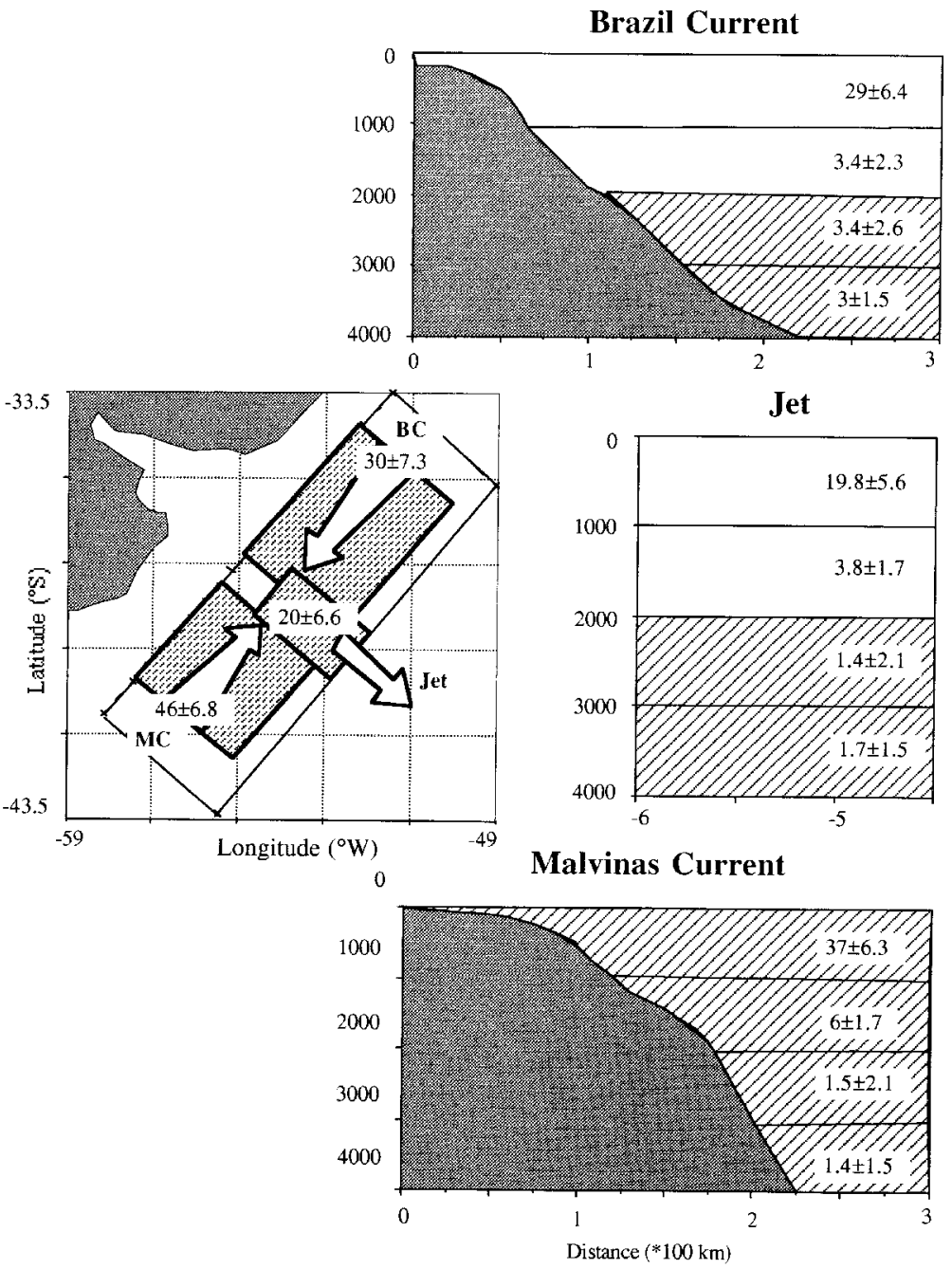

Figure 7. (a) Transport of the Brazil and Malvinas Currents and the Jet for case A (initial reference level of no motion $1500 \mathrm{~m}$ ). The horizontal map gives depth integrated transport. Transport for different layers of each current are given. Striped layers indicate a northward flow for both Brazil and Malvinas Currents whereas they mean a westward flow for the Jet. The transports are averaged from a number of vertical sections chosen within the shaded area corresponding to each current region. Seven sections have been used to compute the transport of the Brazil current. For the Malvinas Current, six sections provide the average transport. For the Jet, according to the bottom depth and the water layer, 5 to 8 sections have been considered. (b) Same except for inversion B (initial reference level of no motion $3000 \mathrm{~m}$ ). 


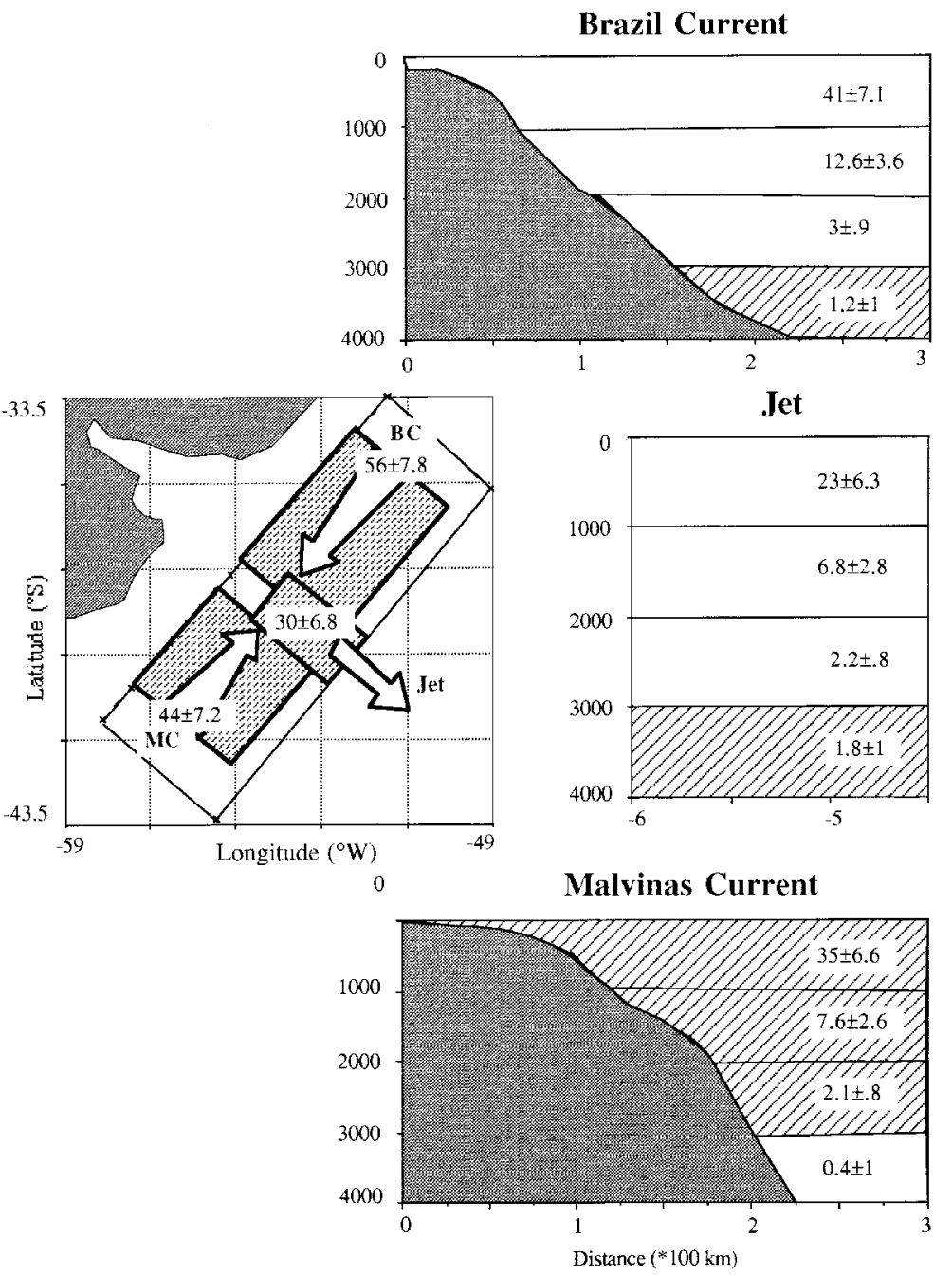

Fig. 7b. (Continued)

the Jet. The low transport values of the jet suggest that most of the waters supplied to the Confluence area are returned back to the north around the Brazil Current region or to the south around the Malvinas Current region. Like the surface layer, the 1000-2000 m layer participates in carrying water in the interior of the Argentine Basin. Beneath the $2000 \mathrm{~m}$ depth, waters are supplied to the Confluence area by a shoreward flow which transports $3 \mathrm{~Sv}$.

Transport values given by cases A and B (Fig. 7b) exhibit no major differences in the Malvinas Current region except in the deepest layer where weak southward flow is observed for case B. Major discrepancies with case A come from transport estimates in the 
Brazil Current and in the Jet regions. The total southward transport of the Brazil Current is now $56 \pm 7 \mathrm{~Sv}$ from which $41 \mathrm{~Sv}$ is attributed to the first thousand meters. In the underneath layer (1000-2000 m), water flows at a rate of $12.6 \pm 4 \mathrm{~Sv}$. Between $2000 \mathrm{~m}$ and $3000 \mathrm{~m}$, a southward transport of $3 \pm 1 \mathrm{~Sv}$ is obtained. The surface layer transport is of the same order as that provided by Zemba (1991) at $34 \mathrm{~S}$ with a level of no motion chosen at the bottom. However at 36S, Zemba (1991) gives a value for the surface layer of $60 \mathrm{~Sv}$ which is larger than here.

In the Jet region, we globally observed an increase in the transport values as compared to case A. Also, a change occurs in the 2000-3000 m layer; water flows seaward. In the deepest layer (3000-4000 m), the Confluence area is supplied with water from the interior of the Argentine Basin.

The total transport given by case B in the bottom layer (depth greater than $3000 \mathrm{~m}$ ) is toward the north with a value of $1 \pm 1 \mathrm{~Sv}$ in accordance with weak northward transport described by previous authors (Reid et al., 1977; Georgi, 1981; Reid, 1989; Peterson, 1992). The total transport in the bottom layer of case $A$ reaches a value of $3 \pm 5 \mathrm{~Sv}$ and water is also carried northward.

On comparing cases A and B, case B gives a water mass circulation scheme in the Confluence area more in accordance with the present knowledge.

\section{Discussion}

In this paper, we provide transport estimates deduced from the data of a 20-day period (February 1990) and from a geostrophic and nonlinear inverse model. This model is applied for the first time to the Confluence of the Brazil and Malvinas Currents. The method used, due to the dynamical and current meter constraints applied in the inversion, gives new transport estimates which are not concordant with previous transport estimates found in the literature.

Many reasons can be invoked to clarify the discrepancies in transport estimates between this work and the previous works. First, our computation method is different from that found in the literature. Most computations have been made through the direct dynamic method. The inverse method has the advantage to adjust the horizontal velocities at the imposed reference level subject to dynamical (Ekman, vorticity and mass conservation) and current meter constraints. This leads to more robust transport estimates with associated errors for the Malvinas and the Brazil Currents. Second, we provide in this paper the transport estimates for the two major currents parallel to the continental slope with a new data set. Our values correspond to more reliable estimates of transport since they are computed in the direction of the flow. Third, a finer resolution is observed in our data set than those used by previous authors. This is the most critical point if we would like to compute the seaward transport component or transport along a steep continental slope. Peterson (1992) finds a seaward geostrophic transport of $143 \mathrm{~Sv}$ across the $4600 \mathrm{~m}$ isobath between $38 \mathrm{~S}$ and $42 \mathrm{~S}$. The values obtained for our seaward Jet are rather small. The region corresponding to our Jet is also smaller than that of Peterson (1992) who estimates the 
transport between 42 and $46 \mathrm{~S}$. The total transport of the Jet is mainly contained in the first thousand meters. The deep western boundary currents propagate more along the slope and undergo intense variability in the Jet region (Maamaatuaiahutapu et al., 1992, 1994; Bianchi et al., 1993; Provost et al., 1995). Then, their contributions to the total seaward transport are weak. Our data set gives a best resolution of the Malvinas Current since CTD station positions are located on the continental slope and the continental shelf. Indeed, a more conclusive comparison can be made with the a priori estimate of transport of the surface layer. An a priori northward transport of $26 \mathrm{~Sv}$ (reference at $1500 \mathrm{~m}$ ) is obtained for the surface layer. Compared to the $10 \mathrm{~Sv}$ of Gordon and Greengrove (1986), this estimate is still higher. Finally, as is often forwarded, a potential error source is nonsynopticity of the data set. This is of course a problem with any hydrographic data set. The Confluence region is known to have strong current variations in the near-surface layers as well as in the deep layers. The proximity of the continental slope also tends to augment the complex pattern of the circulation. Garzoli (1993) shows that in the Confluence region, the transports associated to the different currents are submitted to strong variations on short time scales.

As pointed out, a different approach is adopted here. Ekman, vorticity, mass conservation and current meter constraints have been included within the frame of a geostrophic computation. Except for current meter constraints, sensitivity studies have been carried out on the various constraints by changing their associated error. The inversion performed in the Confluence area is sensitive to the Ekman and vorticity constraints. The errors associated with these two constraints cannot be lowered by a large amount as compared to the values reported in Table 3 because of nonconvergence of the iterative procedure used in the nonlinear inversion. The inversion is less sensitive to the mass conservation. The mass conservation constraint largely depends on the a priori density field which can easily be adjusted with respect to its associated error field. These sensitivity results could reflect missing physics in the dynamical balances which act as a noise floor. This could also be due to our choice of the Ekman layer depth. Zhang (1995) showed, with a linear inverse model, that the results are sensitive to the choice of the thickness of the Ekman layer. The inconvenience of the inverse procedure due to lack of information is that some of the $a$ priori parameters have to be chosen by trial and error or by comparing the Confluence region with another similar but climatologically better known region. However, the associated error of the different constraints given here are thought to be representative values of the Confluence area as evidenced by the sensitivity experiment. In any case, the constraints are compatible with the hydrographic data and the geostrophic dynamic.

The last examination which has been carried out on these inversions is to successively include heat and salt conservations as constraints. These constraints are inserted in the model using the finite-difference scheme like in the case of the mass conservation. By stating that the flow field given by case B is the right one, the heat conservation equations are inserted in order to determine what is the standard deviation associated with the heat constraint which we have to consider to keep the circulation of case B unchanged. We found that a standard deviation of $10^{13} \mathrm{~W}$ should be considered. Associating this standard 
deviation to the vertical flux at the air-sea surface in one cell, this value, which is equivalent to a surface heat flux of $8000 \mathrm{~W} \mathrm{~m}^{-2}$, is excessively high in comparison with the maximum surface flux of $85 \mathrm{~W} \mathrm{~m}^{-2}$ found in the Confluence area (Provost et al., 1996). Decreasing this error for the heat conservation constraint leads to a change in the circulation scheme provided by case B (Maamaatuaiahutapu, 1994). This experiment shows that the eddy contributions or the small-scale processes (mixing or stirring) are not negligible in the Confluence area. The $10^{13} \mathrm{~W}$ is comparable to the heat transport due to small scales for the first thousand meters of the water column (Bianchi et al., 1993; Provost et al., 1995). The same conclusions are drawn from the salt conservation in which a standard deviation of $10^{5} \mathrm{~kg} \mathrm{~s}^{-1}$ is the more adequate for not changing the circulation scheme of inversion B. These last experiments show that if one would like to correctly calculate the transport of heat or salt in a given region, one would have to consider the small-scale processes as mixing or stirring like in the frontal zone of the Confluence area.

Acknowledgments. The authors wish to acknowledge the assistance of all who participated on the Confluence 3 cruise and in particular the whole crew from the N. O. Le Suroit and our Argentinean colleagues Alejandro Bianchi and Ana Paula Osiroff. Two reviewers are thanked for their useful comments and suggestions. KM would like to thank J-F. Minster for his interest, critical discussions, and support. He also thanks Professors M. Tomczak and A. Bonneville for receiving him in their respective laboratory. All the computations were performed on the computer of the Centre National d'Etudes Spatiales. This work is a contribution to the WOCE-France program. The project was funded by a grant of the Centre National de la Recherche Scientifique (PNEDC WOCE) to UMR5566 and LODYC.

\section{REFERENCES}

Bianchi, A. A., C. F. Giulivi and A. R. Piola. 1993. Mixing in the Brazil-Malvinas Confluence. Deep-Sea Res., 40, 1345-1358.

Bower, A. S. 1989. Potential vorticity balances and horizontal divergence along particle trajectories in Gulf Stream meanders east of Cape Hatteras. J. Phys. Oceanogr., 19, 1669-1681.

Bower, A. S. and T. Rossby. 1989. Evidence of cross-frontal exchange processes in the Gulf Stream based on isopycnal RAFOS float data. J. Phys. Oceanogr., 19, 1177-1190.

Bretherton,F. P., R. E. Davis and C. B. Fandry. 1976. A technique for objective analysis and design of oceanographic experiments applied to MODE-73. Deep-Sea Res., 23, 559-581.

Confluence Principal Investigators. 1990. Confluence 1988-1990, An intensive study of the Southwestern Atlantic. EOS, 71(41), 1131-1137.

Fukumori, I. and C. Wunsch. 1991. Efficient representation of the North Atlantic hydrographic and chemical distributions. Prog. Oceanogr., 27, 111-195.

Garzoli, S. L. 1993. Geostrophic velocity and transport variability in the Brazil-Malvinas Confluence. Deep-Sea Res., 40, 1379-1403.

Garzoli, S. L. and Z. Garraffo. 1989. Transports, frontal motions and eddies at the Brazil-Malvinas Confluence. Deep-Sea Res., 36, 681-703.

Georgi, D. T. 1981. Circulation of bottom waters in the Southwestern South Atlantic. Deep-Sea Res., 28A(9), 959-979.

Gill, A. 1982. Atmosphere-Ocean Dynamics. Int. Geophys. Ser., 30, Academic Press, 662 pp.

Gordon, A. L. 1989. Brazil-Malvinas confluence-1984. Deep-Sea Res., 36, 359-384. 
Gordon, A. L. and C. L. Greengrove. 1986. Geostrophic circulation of the Brazil-Falkland confluence. Deep-Sea Res., 33, 573-585.

Hall, M. M. 1986. Horizontal and vertical structure of the Gulf Stream velocity field at 68W. J. Phys. Oceanogr., 16, 1814-1828.

Hogg, N. G. 1987. A least-squares fit of the advective-diffusive equations to Levitus atlas data. J. Mar. Res., 45, 347-375.

Jackson, D. D. 1979. The use of a priori data to resolve non-uniquenessin linear inversion. Geophys. J. Roy. Soc., 57, 137-157.

Kartavtseff, A., C. Provost and F. Vivier. 1993. Confluence 3: Données et courantométrie. Rapport interne LODYC 93/01, 109 pp.

Legeckis, R. and A. L. Gordon. 1982. Satellite observations of the Brazil and Falkland Currents1975 to 1976 and 1978. Deep-Sea Res., 29, 375-401.

Liu, M. and T. Rossby. 1993. Observations of the velocity and vorticity structure of Gulf Stream meanders. J. Phys. Oceanogr., 23, 329-345.

Maamaatuaiahutapu,K. 1994. Etude de la circulation dans la région de Confluence des courants du Brésil et des Malouines. Thèse de Doctorat de l’Université Paul Sabatier (Toulouse), 359 pp.

Maamaatuaiahutapu, K., V. C. Garçon, C. Provost, M. Boulahdid and A. A. Bianchi. 1994. Spring and winter water mass composition in the Brazil-Malvinas Confluence. J. Mar. Res., 52, 397-426.

Maamaatuaiahutapu, K., V. C. Garçon, C. Provost, M. Boulahdid and A. P. Osiroff. 1992. BrazilMalvinas Confluence: water mass composition. J. Geophys. Res., 97(C6), 9493-9505.

Mercier, H., O. Ollitrault and P. Y. Le Traon. 1993. The contribution of Lagrangian floats to the knowledge of the North Atlantic general circulation. J. Phys. Oceanogr., 23, 689-715.

Olson, D., G. Podesta, R. H. Evans and O. Brown. 1988. Temporal variations in the separation of Brazil and Malvinas Currents. Deep-Sea Res., 35, 1971-1990.

Peterson, R. G. 1992. The boundary currents in the western Argentin Basin. Deep-Sea Res., 39, 623-644.

Peterson, R. G. and L. Stramma. 1989. Upper-level circulation in the South Atlantic Ocean. Prog. Oceanogr., 26, 1-73.

Peterson, R. G. and T. Whitworth III. 1989. The subantarctic and polar fronts in relation to deep water masses through the Southwestern Atlantic. J. Geophys. Res., 94, 10817-10838.

Provost, C., S. Gana, V. Garçon, K. Maamaatuaiahutapu and M. England. 1995. Hydrographic conditions during austral summer 1990 in the Brazil-Malvinas Confluence region. J. Geophys. Res, 100(C6), 10655-10678.

Provost, C., V. Garçon and L. Medina Falcon. 1996. Hydrographic conditions in the surface layers over the slope-open ocean transition area near the Brazil-Malvinas Confluence during the austral summer 1990. Cont. Shelf Res, 16, 215-235.

Provost, C., L. Mémery and B. Torres Lista. 1990. Confluence 3: Données CTD-O2. Rapp. interne LODYC91/02, Lab. d'Océanogr. Dyn. and de Climatol., Paris, 188 pp.

Reid, J. L. 1989. On the total geostrophic circulation of the South Atlantic Ocean: flow patterns, tracers, and transports. Prog. Oceanogr., 23, 149-244.

Reid, J. L., W. D. Nowlin, Jr and W. C. Patzert. 1977. On the characteristics and circulation of the southwestern Atlantic Ocean. J. Phys. Oceanogr., 7, 62-91.

Roden, G. I. 1986. Thermohaline fronts and baroclinic flow in the Argentine Basin during the austral spring of 1984. J. Geophys. Res., 91, 5075-5093.

Saunders, P. M. and B. A. King. 1995. Bottom currents derived from a shipborne ADCP on WOCE cruise A11 in the South Atlantic. J. Phys. Oceanogr., 25, 329-347.

Schmitt, R. W., P. S. Bogden and C. E. Dorman. 1989. Evaporation minus precipitation and density fluxes for the North Atlantic. J. Phys. Oceanogr., 19, 1208-1221. 
Stramma, L. 1989. The Brazil Current transport south of 23S. Deep-Sea Res., 36, 639-646.

Tarantola, A. and B. Valette. 1982. Generalized nonlinear problems solved using the least-squares criterion. Rev. Geophys., 20, 219-232.

Zemba, J. C. 1991. The structure and transport of the Brazil Current between 27 and 36 South. Ph.D. thesis, MIT/WHOI, WHOI-91-37.

Zhang, H-M. 1995. Application of an Inverse Model in the Community Modeling Effort Results. Ph.D. Thesis. MIT/WHOI WHOI-95-10.

Zhang, H-M. and N. G. Hogg. 1992. Circulation and water mass balance in the Brazil Basin. J. Mar. Res., 50, 385-420. 